\title{
Adolescents' social needs living with juvenile idiopathic arthritis and their views about digital resources
}

\author{
Imma Beneitez ${ }^{1 *} \mathbb{D}$, Rubén Nieto², Eulàlia Hernández ${ }^{1,3}$ and Mercè Boixadós ${ }^{1}$
}

\begin{abstract}
Background: Juvenile Idiopathic Arthritis (JIA) and its related symptoms (e.g. pain) have been associated with interference in the daily life of adolescents with JIA including their friendships. There is little research in that sense and in consequence, interventions designed to improve this area. The objectives of this study are 1) to gain knowledge about the needs of adolescents with JIA, particularly focused on their friendships; 2) to explore the potential of the Internet to help them, and 3) to determine what kind of online resource would be the best and what elements it should include.
\end{abstract}

Methods: To achieve the proposed objectives we designed a qualitative study including two phases: the first one exploratory (semi-structured interviews) and the following, confirmatory (online focus group).

Results: 14 adolescents were interviewed and 7 participated in the focus group. They reported some social challenges related to their illness: feeling different, criticized by peers, or not believed. Additionally, they specified some of the coping strategies they used, such as disclosing to others that they have JIA, using communication skills, maintaining activities with friends, trying to minimize pain, and ignoring negative comments. Adolescents considered an online resource useful and mentioned that they would like to find general information and to have the possibility to interact with others. They considered Instagram and WhatsApp as good platforms to implement the online resource.

Conclusions: According to their perceptions, adolescents with JIA can benefit from an online resource which delivers information, strategies and facilitates interaction with others.

Keywords: Juvenile idiopathic arthritis, Psychosocial, Pain, Friendship, eHealth

\section{Background}

Juvenile Idiopathic Arthritis (JIA) is the most common chronic rheumatic disease in children, although the epidemiology varies worldwide. For example, in a recent systematic review, the estimated prevalence rates vary between 3.8 and 400/100000 in Europe [1].

JIA is a concept that groups 7 chronic arthritis conditions that have an onset before the age of 16 years, remain for more than 6 weeks, and have an unknown

\footnotetext{
* Correspondence: ibeneitez@uoc.edu

'PSiNET research group, Faculty of Psychology and Education, Universitat Oberta de Catalunya, Rambla Poblenou, 156, 08018 Barcelona, Spain Full list of author information is available at the end of the article
}

origin [2-4]. Pain is a common symptom that can persist despite adequate control of the inflammatory disease [5-7] which frequently persists for a long time and it's difficult to be completely diminished through medication [8-11]. Pain condition is associated with functional disability (e.g. movement limitations) and can cause school and extracurricular activities absenteeism [10, 12-15]. Mentioned physical limitations and the fact that pain is invisible and also unpredictable can make adolescents with JIA feel different from others, not believed or judged [13, 16-24]. Studies have been considered the impact in their overall quality of life $[7,15,25-28]$. However, these negative

(c) The Author(s). 2020 Open Access This article is licensed under a Creative Commons Attribution 4.0 International License, which permits use, sharing, adaptation, distribution and reproduction in any medium or format, as long as you give appropriate credit to the original author(s) and the source, provide a link to the Creative Commons licence, and indicate if changes were made. The images or other third party material in this article are included in the article's Creative Commons licence, unless indicated otherwise in a credit line to the material. If material is not included in the article's Creative Commons licence and your intended use is not permitted by statutory regulation or exceeds the permitted use, you will need to obtain permission directly from the copyright holder. To view a copy of this licence, visit http://creativecommons.org/licenses/by/4.0/. 
experiences living with JIA might result in altered social functioning (including friendships) $[29,30]$ and emotional difficulties such as depression and anxiety [17, 31-33].

Knowing other adolescents with JIA seems to be positive to cope with stigma and misunderstanding $[19,34,35]$ and affects positively to their personal identity. Other studies have described that built friendships based on empathy and comprehension represents huge support [36, 37].

Adolescents are quite used to using the Internet for personal, social, and educational purposes [38]. Adolescents with JIA search information related to their illness (causes, symptoms and living with the JIA) and also visit online peer support forums and social networks $[39,40]$. Despite psychosocial interventions delivered online helps to increase accessibility and comfort [41], there are limited available on the Internet for this population and mainly are designed to promote physical activities [42-44]. It's important to mention that there is available a multicomponent Internet intervention that includes self-management strategies, disease specific information, and social support [45]. Recently, two different groups of researchers have developed a mentoring program for adolescents with JIA to improve selfmanagement and peer support treatments [46] in combination with an App, called JIApp. Mentioned App provide education and support: general information about JIA to help young people to manage their symptoms (medications, physical exercise and counselling), links to webs and forums [47]. Although results of these studies are promising, more research is needed in our context, and especially in relation to online resources oriented toward improving social relations in general (and friendships in particular).

According to the literature reviewed, the specific objectives of this study are: 1) to gain knowledge about adolescents' social needs living with JIA, particularly focused on their friendships; 2) to explore the potential of the Internet to help them); and 3) to determine what kind of online resource would be the best from their point of view and what elements it should include (based on their needs). To achieve the proposed objectives, we designed one study with two parts: phase one, a qualitative study mixing in-depth, semi-structured interviews with an exploratory purpose; and phase two, conducting an online focus group with a confirmatory purpose.

\section{Methods}

\section{Procedure}

The study was approved by the Ethics Committee of the Universitat Oberta de Catalunya.

Participants were recruited from specialized rheumatologic disease units like Hospital Universitario de A Coruña and Hospital Universitario Son Espases and from different patient associations such as Lliga
Reumatológica Catalana, Aspanijer Liga Reumatoloxica Galega and AIJ Euskadi. Additionally, a Facebook page was created to deliver information about the study. In all cases, parents of interested adolescents were informed about the purpose of the study through a phone call. During this contact, inclusion and exclusion criteria were also checked. Those who agreed to participate were asked to sign an informed consent (adolescents also have to agree to participate). Their privacy and confidentiality were guarantee.

Taking into account that participants were from all over the country, video-conference was used for the semi-structured interviews (except in one case where the adolescent preferred a face-to-face interview). For the second phase of the study, an online focus group was designed. The participants didn't know each other, were anonymized by using a nickname and they weren't allowed to contact each other once the focus group finished.

The interview and focus group were conducted by a health psychologist and all data were collected from the workplace.

\section{Participants}

Inclusion criteria were: age between 11 and 18 years old, a diagnosis of JIA based on the International League of Associations for Rheumatology criteria [48], and access to the Internet. Those with a severe mental illness, cognitive problems, and/or a physical disability that keeps them from using the Internet were excluded.

Convenience sampling was used; thereby the adolescents who respond to adverts and invitations and met the inclusion criteria were recruited and interviewed until data saturation was reached, at the time when the codes that emerged during the analysis confirmed the categories obtained, were repeated and redundant [49].

According to previous studies we estimated that a sample between 10 and 18 adolescents were optimal to conduct the interviews [46, 49-53] and between 8 and 14 for the focus group [54-56].

Finally, a total of 14 adolescents were interviewed and 12 other adolescents were invited to participate in the focus group, although only 7 of them participated actively. The reasons for not participating were lack of time due to school assignments. Sociodemographic and pain data were collected through an online questionnaire (created using LimeSurvey).

\section{Semi-structured interview}

A psychologist experienced in evaluation and assessment in the field of health conducted all the interviews. Following Smith [57], a list of topics (agenda) was designed prior to the interviews. This agenda (see Table 1) was 
Table 1 Agenda for the semi-structured interviews

\begin{tabular}{ll}
\hline TOPIC & PURPOSE \\
\hline $\begin{array}{l}\text { Introduction to the interview } \\
\text { Ice breaker questions }\end{array}$ & $\begin{array}{l}\text { To introduce interview objectives and methodology } \\
\text { Questions with very little anticipated emotional content and with the objective of making the } \\
\text { adolescent feel comfortable }\end{array}$ \\
$\begin{array}{l}\text { How they live with pain related to JIA } \\
\text { Friendships }\end{array}$ & $\begin{array}{l}\text { To explore what their pain is like and how they cope with their illness. } \\
\text { Friendships and pain }\end{array}$ \\
$\begin{array}{l}\text { Tow to improve their friendships } \\
\text { Opinion about an online resource and how it } \\
\text { should be }\end{array}$ & $\begin{array}{l}\text { Strategies they would consider useful to improve their friendships } \\
\text { Ending }\end{array}$ \\
\hline
\end{tabular}

created and reviewed by three investigators and two psychologists with experience in rheumatic disease field.

The agenda of topics was the guide for the interview, but it was not exclusive (the interviewer was open to including new topics emerging from the interaction with participants). Moreover, the interviewer was nondirective, allowing participants to freely express their opinions about the general topics in a dialogue. Interviews lasted from 30 to $50 \mathrm{~min}$.

\section{Focus group}

The focus group was carried out using the iTracks software. Adolescents were asked to participate for 9 days, and they were encouraged to connect to the forum at least once a day. There was a moderator who promoted participation and reinforced participants' contributions. Moreover, there were two observers supporting the moderator by giving her feedback and ideas for encouraging participants.

There were two main relevant themes for the study purposes that were introduced with a specific video/animation created for the study. Participants were notified via e-mail once each theme was open. In addition, on the day before the ninth day (the last day that the focus group was open), we sent all participants an e-mail reminding them that the focus group would end soon. Third and seventh day phone-call reminders were planned for those who had not participated. Finally, once the focus group was closed, an email with a summary of the results was sent to all participants to give them the opportunity to check that the conclusions reflected their ideas.

The two main themes, subsequently presented in the online focus group, were the following:

1- What resource would you create?

A summary of the responses given by the participants in the first phase- but limited to those related to the characteristics that an online resource for children with JIA should have- was given to the group. We asked them if these results reflected their opinions. Moreover, in order to obtain new and fresh ideas, they were asked what kind of online resource they would create to help adolescents with JIA.

2- What resource would you choose?

Taking into account the results from the first phase (see results section) and the available literature, we developed four different ideas for an online resource for adolescents with JIA. The main features of each were presented by showing images of how the resource could be viewed, and by explaining its main characteristics and functions. As Table 2 shows, the main functions for each alternative were quite similar. There were differences in the resource proposed, the possibilities for interaction with peers, and the extent to which information was visible to other people outside the study group.

\section{Analysis}

Content analysis [58] was performed using the software Atlas.ti 6.2, in the following four steps: (1) One of the researchers listened to all the audiotapes and transcripts to obtain overall knowledge and identify potential topics; (2) Using the pre-defined guides for the interviews and focus group and the potential topics identified (a deductive and inductive open-coding approach), the researcher developed a coding schema; (3) This researcher and a second researcher independently identified and coded $10 \%$ of the data using the predefined schema. To confirm the coding structure, inter-rater reliability was calculated, and each disagreement was debated until consensus was reached. During this process, if new codes arose, all the audiotapes and transcripts were reviewed to adapt the codes to the new schema. Once the coding schema had been established and each category was well defined (Cohen's Kappa coefficient $\geq$ $0.80)$, (4) the first researcher coded all the remaining data to ensure that the data were representative and that no new codes emerged. 
Table $\mathbf{2}$ Ideas for an online resource for children with JIA

\begin{tabular}{ll}
\hline Idea & Main functionalities \\
\hline Option A: Facebook & - Closed group \\
& - Tips and info on the Facebook wall. Participants comment/rate and share resources on the Facebook wall \\
& - Chat with peers using the messenger system by Facebook \\
& - Profile created for teens with JIA (but open) \\
Option B: Instagram and & - Tips and info published using pictures and videos; information labeled with a hashtag for the intervention \\
WhatsApp & content \\
& - Participants comment/rate and share resources using the hashtag \\
& - Chat with peers using WhatsApp \\
& - Restricted access \\
& - Tips and information will be published inside the Moodle Area \\
Option C: Moodle & - Participants could comment/rate and share resources inside the Moodle group \\
& - Chat with peers using the system available inside Moodle \\
& - Open blog \\
Option D: Blog by Wordpress & - Tips and information will be published using posts \\
& - Participants could comment/rate and share resources using posts \\
& - Chat with peers using WhatsApp \\
\hline
\end{tabular}

\section{Results}

\section{Sample characteristics}

In Table 3, the main characteristics of the sample are presented. No significant differences were found between the two groups for the variables indicated.

The level of participation in the focus group was high for two participants who made different comments about the presentation and about each of the two themes. Four other adolescents also participated in the presentation and the two themes, but with less intensity. Finally, another teen only participated in the presentation, even though the moderator contacted him to encourage his/her participation at different times.

\section{Content analysis from the interviews}

In Table 4, we present all of the identified codes in relation to each topic, as well as a few examples (extracts from the most representative categories). In the following lines, we comment on the contents identified and classified into different categories.

\section{Friendship and pain interference}

The adolescents mentioned that they felt "Satisfaction with their friendship", commenting that there were no aspects to improve, that they felt good or comfortable, and that they could be themselves with their friends. However, some of them also made comments suggesting that there was "Something to improve about friendships",

Table 3 Sociodemographic and pain characteristics

\begin{tabular}{|c|c|c|}
\hline & $\begin{array}{l}\text { Interviews } \\
(N=14)\end{array}$ & $\begin{array}{l}\text { Focus group } \\
(N=7)\end{array}$ \\
\hline Age- Median (SD; range) & $13,93(1,94 ; 11-18)$ & $15,43(2,66 ; 11-18)$ \\
\hline Years since diagnosis- Median (SD; range) & $6,36(2,79 ; 1-12)$ & $6,71(4,43 ; 2-15)$ \\
\hline Gender (\% girls, number) & $78,57 \%(11)$ & $85,71 \%(6)$ \\
\hline Days with pain during past month- Median (SD; range) & $9,43^{*}(8,86 ; 0-28)$ & $14,86(12,36 ; 0-30)$ \\
\hline \multicolumn{3}{|l|}{ Pain frequency during past 3 months (\%) } \\
\hline Almost every day & $28,57 \%$ & $42,86 \%$ \\
\hline Some days & $57,14 \%$ & $42,86 \%$ \\
\hline No & $14,29 \%$ & $14,29 \%$ \\
\hline \multicolumn{3}{|l|}{ Pain intensity- Median (SD; range) } \\
\hline Actual & $2,29 *(2,19 ; 0-6)$ & $3,14(3,36 ; 0-7)$ \\
\hline Worse past 3 months & $7,29^{*}(3,24 ; 0-10)$ & $7,14(2,75 ; 1-10)$ \\
\hline Usual past 3 months & $3,86^{*}(2,70 ; 0-8)$ & $5,29(2,25 ; 1-8)$ \\
\hline \multicolumn{3}{|l|}{ Number of missed school days in the past 3 months } \\
\hline Median (SD; range) & $1,86^{*}(2,29 ; 0-7)$ & $2,14(3,64 ; 0-10)$ \\
\hline
\end{tabular}


Table 4 Categories and codes identified (interviews)

\begin{tabular}{ll}
\hline Categories & Codes \\
\hline $\begin{array}{l}\text { Friendship and pain } \\
\text { interference }\end{array}$ & $\begin{array}{l}\text { Satisfaction with their } \\
\text { friendships } \\
\text { Something to improve } \\
\text { about friendships } \\
\text { Performing physical } \\
\text { activities }\end{array}$ \\
$\begin{array}{ll}\text { Feelings about friendship and } \\
\text { JA }\end{array}$ & $\begin{array}{l}\text { Feeling different } \\
\text { Feeling criticized by } \\
\text { peers } \\
\text { Not feeling believed }\end{array}$ \\
& $\begin{array}{l}\text { Not feeling understood } \\
\text { JA }\end{array}$ \\
Sow they socially cope with & $\begin{array}{l}\text { Self-disclosing that the } \\
\text { have JIA }\end{array}$
\end{tabular}

\%* Examples

78.57 "If I tell them what's going on, they usually help me, and yes, the truth is that I think we can talk about almost anything ..." [Boy, 14 years]

21.43 "... it would increase trust." [Girl, 14 years]

57.14 "If I see that they might tell me we're going to walk to the other side of the city, I might walk a while and then get the bus or just take the bus, or I don't know ..." [Girl, 15 years]

57.14 "I felt physically different when I was medicated, I mean, I was really bloated because of the illness and really bloated because of the medication ..." [Girl, 14 years]

35.71 "One of my classmates 1 day called me -fat ankles- and said that I was pretending..." [Girl, 12 years old]

35.71 "I have had to learn to be patient with people ... because not everyone believes it ..." [Girl, 14 years]

28.57 "...they don't understand... and they don't ask me because they don't dare. They know I have something, but they don't know what it is..." [Girl, 15 years old]

78.57 "I think I don't have anything to keep to myself, that is, I can say everything, and with my friends, I don't care whether I tell them or not. ... Well, if a new kid comes, I won't go and tell him -Hey, I have arthritis-, but if the topic comes up, I will tell him ... I'm not embarrassed either or anything like that ... Most of them are friends from a long time ago, and they already know about it, and so they don't even ask ... If they are interested, I explain it to them, if it's like - Why don't you do gym?- I tell them for no reason and that's that." [Girl, 13 years]

Using communication skills

Maintaining activities

Minimize pain Ignore negative comments

Laugh at pain

Offering a benefit

Needs to better socially cope Information with JIA

ICT use and perceptions about an online resource for JIA for them with friends
Access using a smartphone

Speaking with friends

Searching for information

Watching films, series or listening to music
42.86 "I usually try to reason with them and explain to them that this isn't acting, that I would not use the disease to be dramatic, that this is something serious." [Girl, 14 years]

35.71 "If I am, for example, in the discotheque, well I sit down, and even though sometimes they say -No, I'll stay with you.- and I say -No, you go and follow, I don't mind- And if I see that I feel better, I follow. But ... I try to stop a little, and when I see that I am getting better, well, I go on, even if I'm a little weaker." [Girl, 15 years]

35.71 ".... But we don't usually start to talk like ... - It hurts and I sit down ... -. No, it's

28.57 like, it hurts and continue on." [Girl, 14 years]

"I usually ignore them and say -you know it hurts, you don't have to pay attention to them-" [Girl, 14 years]

14.29 "When I'm in class and I have pain on my leg and I cry out - pulled muscle!- And then they look at me and laugh and I joke because I'm already used to it." [Girl, 15 years old]

14.29 "Sometimes I say -Well, my parents pick me up with car- and I invite some friend who lives nearby to come with me by car." [Girl, 15 years old]

28.57 " ... because at the beginning, they only said -the pain is like that but we don't know why- if they had said that it would keep me from doing things, well I would have accepted gradually, and not all of a sudden, that I would have to stop dancing." [Girl, 15 years]

21.43 "When I'm in the middle of a flare-up, I mean, when I'm bloated or having a flareup, they have to help me to climb the stairs sometimes, even though it seems stupid ..." [Girl, 14 years]

Friends not feeling sorry

21.43 "... but it's like, it's not that it affects me a lot, but I prefer that they don't say Poor thing- because it's something that doesn't affect me very much and there are people who are suffering a lot more than I am, and they really are poor things, so to speak." [Girl, 13 years]

92.86

64.29

42.86

35.71 
Table 4 Categories and codes identified (interviews) (Continued)

\begin{tabular}{|c|c|c|c|}
\hline Categories & Codes & $\%^{*}$ & Examples \\
\hline & Playing & 21.43 & \\
\hline & Using social networks & 85.71 & \\
\hline & $\begin{array}{l}\text { Usefulness of an online } \\
\text { resource for JIA }\end{array}$ & 100 & $\begin{array}{l}\text { "It's pretty interesting because it has to help you a lot and, well, even though you } \\
\text { don't have them (friendship problems) it will always help you in some way, I } \\
\text { suppose, the truth is that it can be really good." [Boy, } 14 \text { years] }\end{array}$ \\
\hline \multirow[t]{8}{*}{$\begin{array}{l}\text { Characteristics of an online } \\
\text { resource for JIA }\end{array}$} & $\begin{array}{l}\text { Include general } \\
\text { information }\end{array}$ & 64.29 & $\begin{array}{l}\text { "As advice, a person who gives advice to others, well, about the topic of friends, } \\
\text { or changes in mood, pain .... and all those things, and so that person, they can } \\
\text { help a lot, to know what to do or what's wrong with her ..." [Girl, } 12 \text { years] }\end{array}$ \\
\hline & $\begin{array}{l}\text { Interactions with other } \\
\text { teens with JIA }\end{array}$ & 50 & \\
\hline & $\begin{array}{l}\text { Interactions with } \\
\text { someone experienced }\end{array}$ & 64.29 & \\
\hline & $\begin{array}{l}\text { Health professionals } \\
\text { should be involved }\end{array}$ & 57.14 & $\begin{array}{l}\text { "Doctors or a psychologist or someone like that who has experience or knows } \\
\text { about that." [Girl, } 12 \text { years] }\end{array}$ \\
\hline & $\begin{array}{l}\text { People without } \\
\text { experience should be } \\
\text { involved }\end{array}$ & 28.57 & \\
\hline & Chat & 28.57 & \\
\hline & Forum & 21.43 & \\
\hline & Web/blog & 14.28 & \\
\hline
\end{tabular}

such as confidence or that their friends should be more patient with them.

"Performing physical activities" that are usually done with friends also emerged as an important topic. Some of them referred to having limitations on activities such as walking, running, cycling, skiing, or dancing. There were also comments about not having limitations in their performance on physical activities, and others suggesting that they have adapted or limited some of their activities.

\section{Feelings about friendship and JIA}

The adolescents made comments about "Feeling different" (or having felt different) from others because of JIA (as a whole, not only pain). Another topic was "Feeling criticized by peers", including comments referring to criticism they have received as a consequence of JIA. There were also comments about "Not feeling believed" and "Not feeling understood" with regard to invisible symptoms such as pain or other symptoms.

\section{How they socially cope with JIA}

Different contents related to coping strategies to manage JIA and/or friendships emerged during the adolescents' discourse. One of them was "Self-disclosing that they have JIA". Adolescents suggested that the decision about whether to self-disclose their condition or not was a controversial topic. From their perspective, it would depend on the level of friendship and the perception of "danger", meaning the evaluation of the probabilities of being seen, for example, as a "weirdo", or the possibility that their friends would not believe their problems.

Other coping strategies mentioned include: "Using communication skills", when they have been in complicated situations related to their illness; "Maintaining activities with friends", with adaptations if needed, despite feeling bad; "Minimizing pain", which means being distracted and going out with friends despite the pain, or not talking about pain or hiding it and continuing their activities; "Ignoring negative comments" from others; "Laughing at pain", joking about their pain condition; and "Offering a benefit". This last category refers to offering a benefit that is attractive to friends (for example that their parents drive them to school).

\section{Needs to better socially cope with JIA}

A general topic that emerged when asked what they need to better manage their friendships was the need for real "Information" about the JIA diagnosis, its characteristics, course, impact, and consequences. Another general topic was that they would need "Physical help" to perform some activities.

Finally, specifically regarding their friendships, they expressed the following things that would help them to better manage their friendships: "Friends not feeling sorry" about their situation.

\section{The use of information and communication technologies (ICT) and perceptions about an online resource for JIA} To explore the potential acceptability of an online resource, some general questions were presented in 
relation to the use of ICT. All the participants stated that they used the Internet, and most of them "Accessed it using a smartphone". The uses of Internet that emerged can be seen in Table 4. All of them also indicated favourable opinions about the "Usefulness of an online resource for JIA".

\section{Characteristics of an online resource for JIA}

Adolescents suggested that the online resource should "Include general information", basically about: essential information about JIA; tips on how to manage JIA; people who can help them; and experiences of others.

"Interaction with other teens" and with "People without experience" were also considered important features that would allow them to share experiences and ask other people questions. They also thought that "Someone experienced" (referring to people in the same situation, but with experience, or people with experience with similar illnesses) and "Health professionals" should be involved.

When asked about the functions the resource should have, adolescents reported different options that can be seen in Table 5.

\section{Content analysis from the focus group}

Results are presented in Table 5 and explained below in relation to the two themes presented for discussion.

\section{What resource would you create?}

In general, responses agreed with results from first phase, and similar codes were defined. Participants confirmed that they would include "Information". However, they gave us more details than in the interviews about what information modalities they would find useful. These included: information about JIA in general, treatment options, prognosis, causes, common problems in everyday life, available resources and tips (for managing JIA related symptoms and doing exercise).

"Interaction with someone experienced" and "Interaction with other teens with JIA" were reinforced as important in the focus group. They further specified the benefits of interacting with other peers (see an example in Table 5). Interestingly, none of the participants in the focus group mentioned that "Health professionals should be involved".

Finally, "Including surveys" in the online resource for children with JIA was suggested.

\section{What resource would you choose?}

Most of the participants said that they would choose the "Instagram and WhatsApp option". Some of them mentioned advantages of this option, which were related to the perception that these tools were used more in their everyday lives. Some disadvantages of this option also emerged, related to the possibility that some adolescents might not have accounts in these two tools. There were

Table 5 Categories and codes identified (focus group)

\begin{tabular}{|c|c|c|c|}
\hline Categories & Codes & $\% *$ & Examples \\
\hline \multirow[t]{4}{*}{$\begin{array}{l}\text { What resource would } \\
\text { you create? }\end{array}$} & Information & 85.71 & $\begin{array}{l}\text { "Personally, I agree with what the people interviewed said. Because I think it is very } \\
\text { important to be informed at all times about JIA." [Girl, } 18 \text { years] } \\
\text { "I already know some of these things, but I would like to know more about them in- } \\
\text { depth." [Girl, } 15 \text { years] }\end{array}$ \\
\hline & $\begin{array}{l}\text { Interaction with } \\
\text { someone experienced }\end{array}$ & 85.71 & $\begin{array}{l}\text { "... I think the best thing would be to be able to contact other patients who have been } \\
\text { treating JIA for more years ... people about thirty or forty years old, I don't know, but } \\
\text { have more experience with it." [Girl, } 17 \text { years] }\end{array}$ \\
\hline & $\begin{array}{l}\text { Interaction with other } \\
\text { teens with JIA }\end{array}$ & 71.43 & $\begin{array}{l}\text { "I would like to know someone I could talk to about these topics and the things that I } \\
\text { often don't have anybody to talk to about. The other person can give you advice just like } \\
\text { you can give her advice." [Girl, } 15 \text { years] }\end{array}$ \\
\hline & Including surveys & 28.57 & $\begin{array}{l}\text { "The surveys could be very different from each other, for example, asking what joints are } \\
\text { most affected, and so being able to contact people who are in the same situation as you } \\
\text { are, or about what you would recommend, in other words, completely different responses } \\
\text { from each other to guide you, that are always welcome, even though each case is } \\
\text { different." [Girl, } 18 \text { years] }\end{array}$ \\
\hline \multirow[t]{4}{*}{$\begin{array}{l}\text { Which resource } \\
\text { would you choose? }\end{array}$} & Option A: Facebook & & $\begin{array}{l}\text { "I think the best tool is Facebook because it is the most comfortable because it includes } \\
\text { chat, and it is the most well-known, so that it is also the one that gives the best options." } \\
\text { [Girl, } 11 \text { years] }\end{array}$ \\
\hline & $\begin{array}{l}\text { Option B: Instagram + } \\
\text { WhatsApp } \\
\text { Option C: Moodle }\end{array}$ & & $\begin{array}{l}\text { "I think the best option would be B, the one with Instagram and WhatsApp, because it is } \\
\text { the combination of the two applications that kids our age use the most. So I think it is } \\
\text { the most accessible option for everyone." [Girl, } 15 \text { years] } \\
\text { "... with the least used pages in google searches, such as Moodle..." [Girl, } 18 \text { years] }\end{array}$ \\
\hline & & & $\begin{array}{l}\text { "I'm not familiar with Moodle because I never use it." } \\
\text { [Girl, } 17 \text { years] }\end{array}$ \\
\hline & Option D: Wordpress & & "... with the least used pages in google searches, such as ... or Wordpress." [Girl, 18 years] \\
\hline
\end{tabular}


also some concerns about confidentiality, due to the fact that personal profiles and phone numbers could be shared with others.

The second most preferred option was "Facebook". Advantages that emerged from this perspective were related to their perception that this is a very well-known tool by adolescents. However, disadvantages of this resource were related to the low perceived frequency of use of Facebook, compared to other tools such as Instagram and WhatsApp.

None of the participants chose Moodle or Blog options. Only two participants made comments about the disadvantages of these tools (not knowing these platforms or not liking them).

\section{Discussion}

Adolescents in our study were satisfied with their friendships. Similar results have been found in other studies $[36,37,59]$ where participants didn't perceive any affect to their friendships since they found friends that helped and understand them. However, and as we expected, they presented physical activities limitations. Pain interference in social activities involving physical activities has been described in the literature $[13,14,19,21,34$, 60]. Although at first it seemed that there was no problem with their friendship, the fact that adolescents revealed some areas of improvement in their friendships, indicates that probably at some point since their diagnosis they have had to face some challenges in certain social situations. This would explain their feelings of being different, criticized by peers, or not believed. These feelings have been mentioned along the studies reviewed $[13,16,18,21,22,34,59]$ under other labels such as stigma or incomprehension [23].

Knowing mentioned social challenges in advance can be the key of prevention, since in this way the capacity and strategies can be put in place to cope with social situations [16]. Probably this point is connected with their desire to obtain general information about JIA and support from their friends. Similar results have been found in other studies where adolescents also developed this need for information on how to manage their life, when and how to talk about JIA or social support [16, 20-23]. It is remarkable to consider that the adolescents interviewed stressed the need they would like to receive information at the beginning of the diagnosis, especially in relation to the consequences of the disease, such as what activities they would have to stop doing. They might want to know how the disease would impact their lives and the possibility of being victims of bullying, as participants from other study have shown [16].

Most of the adolescents talk about the coping strategies they have developed since diagnosis. These are: disclosing to others that they have JIA, using communication skills, maintaining activities with friends, trying to minimize pain, and ignoring negative comments. Different studies have described similar strategies [13, 20, 22, 23, 59].

Focus group participants' discussed that they would like to interact with someone experienced with JIA. Connected to this, other study [22] has shown the desire to know other experiences: how others had learned to live with JIA or different ways of talking about illness with others or the social and emotional experiences of living with JIA [16, 35]. According to a large number of studies, knowing other children with JIA is beneficial $[13,18-20,23,34,35,59]$ by promoting feelings of normality that help them not to feel different, to feel less isolated and more understood by children who experience similar difficulties and fears.

Adolescents are heavy users of the Internet, preferably use their Smartphone, and mainly to speak with friends through social networks and search for information. They are in favour of obtaining information about JIA, and interact with others, including people with experience with the JIA (peers or health professionals) through an online resource.

Regarding the options proposed for the implementation of the resource, the adolescents who participated in the focus group showed their preference for the social networks of Instagram and WhatsApp. These results are in agreement with the high use of these two apps among adolescents $[61,62]$ and their preferences for interacting with others, as discussed in the previous paragraph, and their great interest in online social activities [39]. Although their potential has been suggested for health [61], they have rarely been used. In this direction, a recently study [63] reviewed the literature about these two tools and found that WhatsApp has mainly been used in clinical decision-making and patient healthcare, and Instagram has been used for informative or motivational purposes. These two tools give us an extraordinary opportunity to facilitate the interaction requested by adolescents.

Following adolescents' suggestions, include the figure of a mentor (with experience in managing JIA) might be a good option to transmit knowledge and training in strategies than some of these adolescents have already been acquired (e.g. communication skill strategies and self-disclosure management). These contents will help them to speak about their illness when they consider it appropriate and ask for help in a natural and assertive way $[64,65]$. It's also important include general information about JIA and strategies to help them to continue their activities. It's important to note that answers indicate that they would like to receive information about the illness as a whole, representing pain or friendships a part of it. The difference between this potential online 
resource and other available $[14,16,17]$ is the inclusion of friendship approach, meaning increasing their competences to deal social situations in relation to JIA.

In addition, Instagram and WhatsApp offer the possibility of commenting on contents and communicating with peers. Looking at the literature, only one recent study was designed to facilitate interactions among peers with JIA, showing outstanding results [46]. Based on this study and others available in the literature on peersupport interventions [66], we hypothesize that this helpful resource will be very well accepted by adolescents.

Despite the studies referenced which support our results, this study is not exempted from limitations. Due to the online nature of this study, the parents' influences in the adolescents' answers were not totally controlled. The sample might represent a major bias since only most motivated adolescents usually participate in patient associations or social networks; further, only those with Internet skills may have been selected. It might explain in part the small sample recruited from which is difficult obtain consistent results.

Additionally, we have to acknowledge that we have focused on adolescents with JIA, but it would also have been useful to gather the views of friends of these adolescents. They could have provided important information for designing our resource, explaining what they would find useful to help their friends with JIA. Based on their opinions, specific contents could have been designed for them. This is a future research path that we will consider. Apart from this limitation, we want to highlight that our study combines two different qualitative strategies and provides an exploratory and confirmatory perspective that can be useful for future research studies.

\section{Conclusions}

The results of this qualitative study may be important to help researchers and health professionals to advance in the design of online helpful resources aiming to manage JIA in adolescents and to improve their abilities to strengthen their social networks, as friends are central figures in adolescents' life and can represent an important support system to manage pain.

\section{Acknowledgements}

The authors would like to thank all adolescents for their participation.

\section{Authors' contributions}

All authors participated in the study design. I.B. coordinated the study, recruited, interviewed and conducted the focus group, and collected data from participants. I.B., E.H., R.N. and M.B. participated in the data analysis. R.N. and I.B. conducted a literature review and drafted the manuscript. All authors revised and approved the final manuscript.

\section{Funding}

This work was supported by a doctoral grant from the UOC PhD Doctoral Fellowship (to I.B.)

\section{Availability of data and materials}

The datasets used and/or analysed in this research are not available in order to don't compromise participants' privacy.

\section{Ethics approval and consent to participate}

This study was approved by the UOC research ethic committee of the Universitat Oberta de Catalunya. All participants signed an informed consent form.

Consent for publication

Not applicable.

\section{Competing interests}

All authors declare no competing interests.

\section{Author details}

${ }^{1}$ PSiNET research group, Faculty of Psychology and Education, Universitat Oberta de Catalunya, Rambla Poblenou, 156, 08018 Barcelona, Spain. 2eHealth Lab, Faculty of Health Sciences, Universitat Oberta de Catalunya, Barcelona, Spain. ${ }^{3}$ UOC eHealth Center, Universitat Oberta de Catalunya, Barcelona, Spain.

Received: 19 March 2020 Accepted: 29 June 2020

Published online: 08 July 2020

\section{References}

1. Thierry S, Fautrel B, Lemelle I, Guillemin F. Prevalence and incidence of juvenile idiopathic arthritis: a systematic review. Joint Bone Spine. 2014;81: 112-7. https://doi.org/10.1016/j.jbspin.2013.09.003.

2. Martini A, Lovell DJ. Juvenile idiopathic arthritis: state of the art and future perspectives. Ann Rheum Dis. 2010;69:1260-3. https://doi.org/10.1136/ard. 2010.133033.

3. Prakken B, Albani S, Martini A. Juvenile idiopathic arthritis. Lancet. 2011;377: 2138-49. https://doi.org/10.1016/S0140-6736(11)60244-4.

4. Ravelli A, Martini A. Juvenile idiopathic arthritis. Lancet. 2007;369:767-78. https://doi.org/10.1016/S0140-6736(07)60363-8.

5. De Lalouvière LLH, loannou Y, Fitzgerald M. Neural mechanisms underlying the pain of juvenile idiopathic arthritis. Nat Rev Rheumatol. 2014;10:205-11. https://doi.org/10.1038/nrrheum.2014.4.

6. Schanberg LE, Lefebvre JC, Keefe FJ, Kredich DW, Gil KM. Pain coping and the pain experience in children with juvenile chronic arthritis. Pain. 1997;73: 181-9. https://doi.org/10.1016/S0304-3959(97)00110-3.

7. Weiss JE, Luca NJC, Boneparth A, Stinson J. Assessment and Management of Pain in juvenile idiopathic arthritis. Pediatr Drugs. 2014;16:473-81.

8. Bromberg MH, Connelly M, Anthony KK, Gil KM, Schanberg LE. Self-reported pain and disease symptoms persist in juvenile idiopathic arthritis despite treatment advances: an electronic diary study. Arthritis Rheum. 2014;66:4629. https://doi.org/10.1002/art.38223.

9. Consolaro A, Ravelli A. Paediatric rheumatology: juvenile idiopathic arthritis are biologic agents effective for pain? Nat Rev Rheumatol. 2013;9:447-8. https://doi.org/10.1038/nrrheum.2013.108.

10. Schanberg LE, Anthony KK, Gil KM, Maurin EC. Daily pain and symptoms in children with polyarticular arthritis. Arthritis Rheum. 2003;48:1390-7. https:// doi.org/10.1002/art.10986.

11. Kimura Y, Walco GA, Sugarman E, Conte PM, Schanberg LE. Treatment of pain in juvenile idiopathic arthritis: a survey of pediatric rheumatologists. Arthritis Care Res. 2006;55:81-5. https://doi.org/10.1002/ art.21689.

12. Bouaddi I, Rostom S, El Badri D, Hassani A, Chkirate B, Amine B, HajjajHassouni N. Impact of juvenile idiopathic arthritis on schooling. BMC Pediatr. 2013;13:2. https://doi.org/10.1186/1471-2431-13-2.

13. Cartwright T, Fraser E, Edmunds S, Wilkinson N, Jacobs K. Journeys of adjustment: the experiences of adolescents living with juvenile idiopathic arthritis. Child Care Health Dev. 2015;41:734-43. https://doi. org/10.1111/cch.12206.

14. Cavallo S, April KT, Grandpierre V, Mainemer A, Feldman DE. Leisure in children and adolescents with juvenile idiopathic arthritis: a systematic 
review. PLoS One. 2014;9:e104642. https://doi.org/10.1371/journal.pone. 0104642.

15. Haverman L, Grootenhuis MA, van den Berg JM, et al. Predictors of healthrelated quality of life in children and adolescents with juvenile idiopathic arthritis: results from a web-based survey. Arthritis Care Res. 2012;64:694703. https://doi.org/10.1002/acr.21609.

16. Barlow JH, Shaw KL, Harrison K. Consulting theexperts': children's and parents' perceptions of psycho-educational interventions in the context of juvenile chronic arthritis. Health Educ Res. 1999;14:597-610. https://doi.org/ 10.1093/her/14.5.597

17. Bomba M, Meini A, Molinaro A, Cattalini M, Oggiano S, Fazzi E, et al. Body experiences, emotional competence, and psychosocial functioning in juvenile idiopathic arthritis. Rheumatol Int. 2013;33:2045-52. https://doi.org/ 10.1007/s00296-013-2685-4.

18. Östlie IL, Johansson I, Möller A. Struggle and adjustment to an insecure everyday life and an unpredictable life course: living with juvenile idiopathic arthritis from childhood to adult life-an interview study. Disabil Rehabil. 2009;3:666-74. https://doi.org/10.1080/09638280802305986.

19. Sällfors C, Fasth A, Hallberg LM. Oscillating between hope and despair - a qualitative study. Child Care Health Dev. 2002;28:495-505. https://doi.org/10. 1046/j.1365-2214.2002.00300.x.

20. Sällfors C, Hallberg LR. Fitting into the prevailing teenage culture: a grounded theory on female adolescents with chronic arthritis. Int I Qual Stud Health Well-being. 2009;4:106-14. https://doi.org/10.1080/ 17482620802431862.

21. Secor-Turner M, Scal P, Garwick A, Horvath K, Wells CK. Living with juvenile arthritis: adolescents' challenges and experiences. J Pediatr Health Care. 2011;25:302-7. https://doi.org/10.1016/.jpedhc.2010.06.004.

22. Stinson JN, Petroz GC, Stevens BJ, Feldman BM, Streiner D, McGrath PJ, Gill $N$. Working out the kinks: testing the feasibility of an electronic pain diary for adolescents with arthritis. Pain Res Manag. 2008;13:375-82. https://doi. org/10.1155/2008/326389.

23. Tong A, Jones J, Craig JC, Singh-Grewal D. Children's experiences of living with juvenile idiopathic arthritis: a thematic synthesis of qualitative studies Arthritis Care Res. 2012;64:1392-404. https://doi.org/10.1002/acr.21695.

24. Yadav A, Yadav TP. A study of school adjustment, self-concept, self-esteem, general wellbeing and parent child relationship in juvenile idiopathic arthritis. Indian J Pediatr. 2013;80:199-206. https://doi.org/10.1007/s12098012-0804-y.

25. Adam V, Saint-Pierre Y, Fautrel B, Clarke AE, Duffy CM, Renrod J. What is the impact of adolescent arthritis and rheumatism (AAR)? Evidence of a national sample of Canadians. J Rheumatol. 2005;32:354-61.

26. Lundberg V, Lindh V, Eriksson C, Petersen S, Eurenius E. Health-related quality of life in girls and boys with juvenile idiopathic arthritis: self-and parental reports in a cross-sectional study. Pediatr Rheumatol Online J. 2012; 10:33. https://doi.org/10.1186/1546-0096-10-33

27. Munro J, Singh-Grewal D. Juvenile idiopathic arthritis and pain - more than simple nociception. J Rheumatol. 2013;40:1037-9. https://doi.org/10.3899/ jrheum.130557.

28. Shaw KL, Southwood TR, Duffy CM, McDonagh JE. Health-related quality of life in adolescents with juvenile idiopathic arthritis. Arthritis Care Res. 2006; 55:199-207. https://doi.org/10.1002/art.21852.

29. Forgeron PA, King S, Stinson J, McGrath PJ, Macdonald AJ, Chambers CT. Social functioning and peer relationships in children and adolescents with chronic pain : a systematic review. Pain Res Manag. 2010;15:27-41. https:// doi.org/10.1155/2010/820407.

30. Gauntlett-Gilbert J, Kavirayani A, Clinch J. Physical and social functioning in adolescents with rheumatological conditions: a study of predictors. Acta Paediatr. 2013;102. https://doi.org/10.1111/apa.12094.

31. LeBovidge JS, Lavigne JV, Donenberg GR, Miller ML. Psychological adjustment of children and adolescents with chronic arthritis: a metaanalytic review. J Pediatr Psychol. 2003;28:29-39. https://doi.org/10.1093/ jpepsy/28.1.29

32. LeBovidge JS, Lavigne JV, Miller ML. Adjustment to chronic arthritis of childhood: the roles of illness-related stress and attitude toward illness. J Pediatr Psychol. 2005;30:273-86. https://doi.org/10.1093/jpepsy/jsi037.

33. Sandstrom MJ, Schanberg LE. Brief report: peer rejection, social behavior, and psychological adjustment in children with juvenile rheumatic disease. J Pediatr Psychol. 2004;29:29-34. https://doi.org/10.1093/jpepsy/jsh004.

34. Hackett J, Johnson B, Shaw KL, McDonagh JE. Friends united: an evaluation of an innovative residential self-management programme in adolescent rheumatology. Br J Occup Ther. 2005;68:567-73. https://doi.org/10.1177/ 030802260506801206

35. Shaw KL, Southwood TR, McDonagh JE. User perspectives of transitional care for adolescents with juvenile idiopathic arthritis. Rheumatology. 2004; 43:770-8. https://doi.org/10.1093/rheumatology/keh175.

36. Eyckmans L, Hilderson D, Westhovens R, Wouters C, Moons P. What does it mean to grow up with juvenile idiopathic arthritis? A qualitative study on the perspectives of patients. Clin Rheumatol. 2011;30:459-65. https://doi. org/10.1007/s10067-010-1444-0

37. Kyngäs H. Support network of adolescents with chronic disease: adolescents' perspective. Nurs Health Sci. 2004;6:287-93. https://doi.org/10. 1111/j.1442-2018.2004.00207.x.

38. Lenhart A, Duggan M, Perrin A, Stepler R, Rainie H, Parker. Teens, social media \& technology overview. Pew Research Center 2015 Available from: http://www.pewinternet.org/2015/04/09/teens-social-media-technology-2 015/.

39. Johnson KR, Fuchs E, Horvath KJ, Scal P. Distressed and looking for help internet intervention support for arthritis self-management. J Adolesc Health. 2015;56:666-71. https://doi.org/10.1016/.j.jadohealth.2015.02.019.

40. van Pelt PA, Drossaert CH, Kruize AA, Huisman J, Dolhain RJ, Wulffraat NM. Use and perceived relevance of health-related internet sites and online contact with peers among young people with juvenile idiopathic arthritis. Rheumatol. 2015;54:1833-41. https://doi.org/10.1093/rheumatology/kev193.

41. Griffiths F, Lindenmeyer A, Powell J, Lowe P, Thorogood M. Why are health care interventions delivered over the internet? A systematic review of the published literature. J Med Internet Res. 2006;8:e10.

42. Armbrust W, Bos JJ, Cappon J, et al. Design and acceptance of Rheumates@work, a combined internet-based and in person instruction model, an interactive, educational, and cognitive behavioral program for children with juvenile idiopathic arthritis. Pediatr Rheumatol Online J. 2015; 13:31. https://doi.org/10.1186/s12969-015-0029-5.

43. Armbrust W, Bos GJF, Wulffraat NM, et al. Internet program for physical activity and exercise capacity in children with juvenile idiopathic arthritis: a multicenter randomized controlled trial. Arthritis Care Res. 2016;69:1040-9. https://doi.org/10.1002/acr.23100.

44. Lelieveld OT, Armbrust W, Geertzen JH, et al. Promoting physical activity in children with juvenile idiopathic arthritis through an internet-based program: results of a pilot randomized controlled trial. Arthritis Care Res. 2010;62:697-703. https://doi.org/10.1002/acr.20085.

45. Stinson JN, McGrath PJ, Hodnett ED, et al. An internet-based selfmanagement program with telephone support for adolescents with arthritis: a pilot randomized controlled trial. J Rheumatol. 2010;37:1944-52. https://doi.org/10.3899/jrheum.091327.

46. Stinson J, Kohut SA, Forgeron P, et al. The iPeer2Peer program: a pilot randomized controlled trial in adolescents with juvenile idiopathic arthritis. Pediatr Rheumatol Online J. 2016;14:48. https://doi.org/10.1186/ s12969-016-0108-2.

47. Cai RA, Beste D, Chaplin H, et al. Developing and evaluating JIApp: acceptability and usability of a smartphone app system to improve selfManagement in Young People with Juvenile Idiopathic Arthritis. JMIR mHealth uHealth. 2017:5:8. https://doi.org/10.2196/mhealth.7229.

48. Merino R, De Inocencio J, García-Consuegra J. Evaluation of revised (Edmonton 2001) ILAR classification criteria for juvenile idiopathic arthritis in Spanish children. J Rheumatol. 2005;32:559-61.

49. Kerr C, Nixon A, Wild D. Assessing and demonstrating data saturation in qualitative inquiry supporting patient-reported outcomes research. Expert Rev Pharm Out. 2010;10:269-81. https://doi.org/10.1586/erp.10.30.

50. Forgeron PA, Evans J, McGrath PJ, Stevens B, Finley GA. Living with difference: exploring the social self of adolescents with chronic pain. Pain Res Manag. 2013;18:e115-23. https://doi.org/10.1155/2013/120632.

51. Hennink MM, Kaiser BN, Marconi VC. Code saturation versus meaning saturation: how many interviews are enough? Qual Health Res. 2017;27:591608. https://doi.org/10.1177/1049732316665344.

52. Kohut AS, Stinson JN, Forgeron P, Luca S, Harris L. Been there, done that: the experience of acting as a young adult Mentor to adolescents living with chronic illness. J Pediatr Psychol. 2017;42:962-9. https://doi.org/10.1093/ jpepsy/jsx062.

53. Nieto R, Hernández E, Boixadós M, Huguet A, Beneitez I, McGrath P. Testing the feasibility of DARWeb: an online intervention for children with functional abdominal pain and their parents. Clin J Pain. 2015;31:493-503. https://doi.org/10.1097/AJP.0000000000000199. 
54. Carter B, Lambrenos K, Thursfield J. A pain workshop: an approach to eliciting the views of young people with chronic pain. J Clin Nurs. 2002;11: 753-62. https://doi.org/10.1046/j.1365-2702.2002.00642.x.

55. Mackner LM, Ruff JM, Vannatta K. Focus groups for developing a peer mentoring program to improve self-management in pediatric inflammatory bowel disease. J Pediatr Gastroenterol Nutr. 2014;59:487-92. https://doi.org/ 10.1097/MPG.0000000000000473.

56. Williams S. Understanding anorexia nervosa: an online phenomenological approach. Edinburgh: Queen Margaret University; 2009. Available from: http://etheses.qmu.ac.uk/135/.

57. Smith JA. Semi-structured interviewing and qualitative analysis. In: Smith JA Hark R, Van Langenhove L, editors. Rethinking methods in psychology. 1st ed. London: Sage; 1995. p. 8-26.

58. Elo S, Kyngäs $H$. The qualitative content analysis process. J Adv Nurs. 2008; 62:107-15. https://doi.org/10.1111/j.1365-2648.2007.04569.x

59. De Monte R, Rodger S, Jones F, Broderick S. Living with juvenile idiopathic arthritis: children's experiences of participating in home exercise programmes. Br J Occup Ther. 2009;72:357-65. https://doi.org/10.1177/ 030802260907200806 .

60. Abu-Saad HH, Uiterwijk M. Pain in children with juvenile rheumatoid arthritis: a descriptive study. Pediatr Res. 1995;38:194. https://doi.org/10. 1203/00006450-199508000-00010.

61. Landr M, Vyas A, Turner M, Glick S, Wood S. Evaluation of social media utilization by Latino adolescents: implications for mobile health interventions. JMIR mHealth uHealth. 2015;3:e89. https://doi.org/10.2196/ mhealth.4374.

62. Reolid-Martinez RE, Flores M, Lopez M, Alcantud P, Ayuso MC, Escobar F. Frequency and characteristics of internet use by Spanish teenagers. A crosssectional study. Arch Argent Pediatr. 2016;114:6-13. https://doi.org/10.5546/ aap.2016.eng.6.

63. Kamel MN, Giustini DM, Wheeler S. Instagram and WhatsApp in health and healthcare: an overview. Future Internet. 2016;8:37. https://doi.org/10.3390/ fi8030037.

64. Imms C, Mathews S, Richmond KN, Law M. Ullenhag. Optimising leisure participation: a pilot intervention study for adolescents with physical impairments. Disabil Rehabil. 2016;38:963-71. https://doi.org/10.3109/ 09638288.2015 .1068876$.

65. Stewart M, Barnfather A, Magill-Evans J, Ray L, Letourneau N. Brief report: an online support intervention: perceptions of adolescents with physical disabilities. J Adolesc. 2011;34:795-800. https://doi.org/10.1016/j. adolescence.2010.04.007.

66. Kohut SA, Stinson JN, Giosa L, Luca S, van Wyk M. Systematic review of peer support interventions for adolescents with chronic illness: a narrative analysis. Int J Child Adolesc Health. 2014;7:183-97 https//doi.org/.

\section{Publisher's Note}

Springer Nature remains neutral with regard to jurisdictional claims in published maps and institutional affiliations.

Ready to submit your research? Choose BMC and benefit from:

- fast, convenient online submission

- thorough peer review by experienced researchers in your field

- rapid publication on acceptance

- support for research data, including large and complex data types

- gold Open Access which fosters wider collaboration and increased citations

- maximum visibility for your research: over $100 \mathrm{M}$ website views per year

At $\mathrm{BMC}$, research is always in progress.

Learn more biomedcentral.com/submissions 